\title{
DESAIN DAN PEMODELAN SISTEM PEMBANGKIT LISTRIK BERBASIS POLISI TIDUR \\ (Studi pengaruh variasi kecepatan kendaraan terhadap respon speed bump model massa-pegas-peredam)
}

\author{
SETIANTO*, LIU KIN MEN, ANDRI ABDURROCHMAN \\ Departemen Fisika, FMIPA, Universitas Padjadjaran \\ Jl. RayaBandung-Sumedang Km.21 Jatinangor 45363, Sumedang, Jawa Barat, Indonesia \\ *email : setianto@phys.unpad.ac.id
}

\begin{abstract}
Abstrak. Polisi tidur biasanya digunakan untuk mengontrol kecepatan kendaraan dan juga berfungsi sebagai keamanan pejalan kaki. Dalam makalah ini kami mengusulkan desain dan pemodelan sebuah polisi tidur yang dapat menghasilkan energi listrik hingga beberapa ratus watt. Mekanisme gerakan kendaraan yang melewati polisi tidur memungkinkan gerakan naik dan turun yang akan diubah menjadi energi listrik oleh generator. Dalam makalah ini akan dibahas mekanisme respon kecepatan turun speed bump terhadap variasi kecepatan kendaraan dengan cara pemodelan fisik dan simulasinya. Kecepatan turun maksimum yang dihasilkan dari desain speed bump ini kurang lebih $2,3 \mathrm{~m} / \mathrm{s}$ ketika sebuah kendaraan melewati prototipe ini dengan kecepatan rata-rata $5 \mathrm{~km} / \mathrm{jam}$.
\end{abstract}

Kata kunci : polisi tidur/speed bump, energi listrik, pemodelan fisik, simulasi

\begin{abstract}
Speed bump is typically used to control the speed of the vehicle and also serves as a pedestrian safety. In this paper we propose the design and modeling of a speed bump that can generate electricity up to several hundred watts. The mechanism of movement of vehicles that pass through bumps allow movement up and down is converted into electrical energy by a dc generator. In this paper will discuss the mechanism of speed down response the speed bump to the variation of vehicle speed by means of physical modeling and simulation. As result, the maximum speed down of this speed bump design is approximately $2.3 \mathrm{~m} / \mathrm{s}$ when a vehicle passes this prototype with an average speed of $5 \mathrm{~km} / \mathrm{h}$.
\end{abstract}

Keywords : bump/speed bump, electrical energy, physical modeling, simulation

\section{Pendahuluan}

Sebuah polisi tidur pada dasarnya adalah sebuah profil permukaan dengan tinggi 3-5 inchi yang ditempatkan pada seberang jalan [1]. Biasanya dipasang di daerah dengan pemukian dengan interaksi antara manusia dan kendaraan bermotor relatif tinggi untuk mengurangi resiko kecelakaan [2]. Pengurangan kecepatan kendaraan saat menghadapi polisi tidur tidak hanya berpengaruh terhadap kenyamanan berkendara pengemudi atau penumpang, tetapi juga mengakibatkan hilangnya energi kinetik yang besar pada waktu yang sama. Salah satu cara untuk menghasilkan energi alternatif adalah dengan cara memanen energi dari suatu mekanisme. Salah satu contoh mekanisme tersebut adalah mekanisme pada polisi tidur atau speed bump. 
Selama ini polisi tidur atau speed bump hanya digunakan untuk memperlambat laju kendaraan yang melewati jalan, padahal jumlah kendaraan yang melewati polisi tidur tersebut sangat banyak tiap harinya. Berbagai upaya telah dilakukan untuk meningkatkan kenyamanan pengemudi/penumpang saat melewati polisi tidur dengan mengoptimalkan bentuk dan ketinggian speed bump [3,4,5]. Ada juga usaha untuk mengambil energi dari polisi tidur dengan prinsip perangkat piezoelektrik atau elektromagnetik [6,7]. Energi yang dimanfaatkan biasanya relatif kecil dengan tegangan impuls sebesar $20 \mathrm{~V}$ untuk kasus tertentu.

Pada makalah ini dijelaskan mengenai teknologi pembangkit energi listrik energi melalui polisi tidur sebagai sumber energi terbarukan menggunakan sebuah model Speed Bump Energy Harvester (SBEH) yang dirancang berdasarkan mekanisme konversi energi yang disebut dengan Mechanical Motion Rectifier (MMR). MMR mengkonversi gerakan impuls ke bawah dan ke atas polisi tidur dalam satu putaran arah generator listrik untuk menghasilkan energi listrik. Pemodelan SBEH dan interaksinya dengan kendaraan dijelaskan dengan menggunakan persamaan matematis secara detail. Pengaruh variasi kecepatan kendaraan terhadap respon kecepatan turun speed bump model massa-pegas-peredam akan diteliti secara lengkap. Hasil simulasi ini akan digunakan sebagai dasar untuk pembuatan prototipe pembangkit listrik berbasis polisi tidur.

\section{Model Eksperimen}

Berbeda dengan polisi tidur konvensional yang memberikan profil ketinggian tetap, desain pembangkit listrik berbasis polisi tidur ini bisa bergerak ke atas dan ke bawah dan memiliki interaksi secara dinamis dengan kendaraan yang melintasinya. Dengan cara memodifikasi speed bump agar dapat mengubah energi kinetik dan potensial speed bump kemudian diubah menjadi energi listrik pada saat menggerakkan generator ketika kendaraan melintasi speed bump. Untuk mempermudah analisis, diasumsikan bahwa kendaraan yang melewati polisi tidur memiliki kecepatan konstan, dengan demikian kecepatan horizontal ban sama dengan kecepatan kendaraan. Kecepatan kendaraan bernilai konstan saat kendaraan melewati speed bump yaitu 5 km/jam, 10 km/jam dan 15 km/jam.

\subsection{Model Speed Bump Energy Harvester (SBEH)}

Persamaan respon gerak terhadap impuls dapat diaplikasikan pada speed bump dengan cara menggunakan model Speed Bump Energy Harvester (SBEH). Hal ini dikarenakan pada speed bump tersebut mendapatkan impuls sesaat saat dilalui oleh kendaraan. Untuk periode waktu yang sangat singkat, merujuk pada dinamika speed bump ini kita dapat mengetahui bahwa impulse dapat dihitung dengan cara mencari perubahan momentum dari speed bump sebagai akibat dari beban oleh kendaraan yang melewati speed bump. Ketika kendaraan yang melewati SBEH, interaksi antara kendaraan dan SBEH jauh lebih kompleks karena bergerak kondisi batas interaktif antara ban dan kecepatan profil penutup speed bump [8]. Titik berat mobil dapat dicari dengan menimbang tekanan roda depan dan belakang. Setelah itu, dengan mengangkat roda belakang kendaraan menggunakan dongkrak, maka akan diperoleh sudut kemiringan $\theta$ yang nantinya akan dipakai untuk menentukan besarnya tinggi titik berat dari poros roda $(h r)$. Gaya tekan kendaraan digunakan untuk mengetahui beban yang diterima speed bump ketika dilewati kendaraan. 

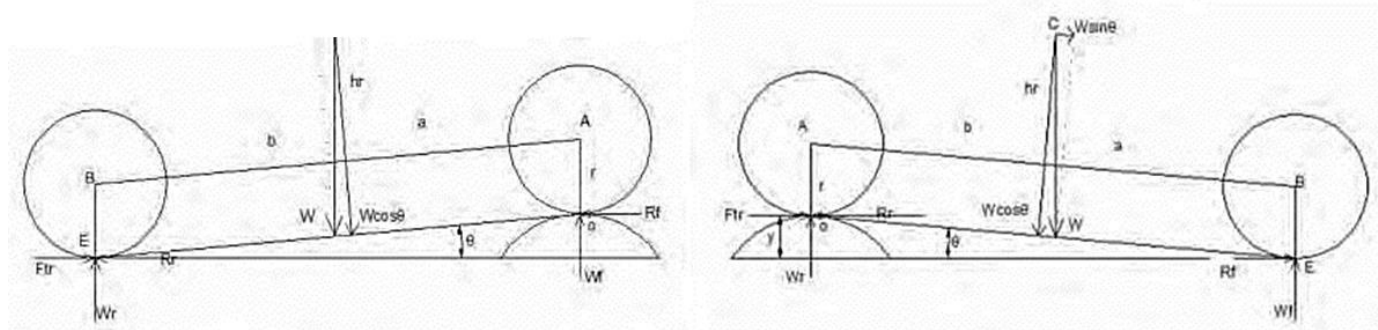

Gambar 2. Model interaksi antara SBEH dengan gaya tekan roda depan dan belakang kendaraan

Ketika kendaraan berinteraksi dengan model SBEH, berat kendaraan yang diberikan pada penutup speed bump akan bergerak secara vertikal ke bawah. Besarnya gaya tekan roda kendaraan dapat dianalisis dengan persamaan:

$$
\begin{aligned}
& W f=\frac{W(h r+r) \cdot \sin \theta+W \cdot b \cdot \cos \theta+R f \cdot \cos \theta}{(a+b) \cdot \sin \theta} \quad(\text { roda depan }) \\
& W r=\frac{W \cdot a \cdot \cos \theta-W(h r+r) \sin \theta-F t r \cdot \cos \theta \cdot y+R r \cdot \cos \theta \cdot y}{(a+b) \sin \theta} \quad \text { (roda belakang) }
\end{aligned}
$$

dengan $W_{f / r}$ adalah gaya tekan roda depan/belakang $(\mathrm{N}), R_{f / r}$ adalah rolling resintance roda depan/belakang $(\mathrm{N}), y$ merupakan tinggi lintasan speed bump $(\mathrm{m})$, $W$ adalah berat total kendaraan $(\mathrm{N})$, Ftr adalah gaya dorong kendaraan pada roda belakang $(\mathrm{N}), a$ adalah jarak posisi titik berat kendaraan terhadap poros roda depan $(\mathrm{m})$ dan $b$ adalah jarak posisi titik berat kendaraan terhadap poros roda belakang $(\mathrm{m})$. Sedangkan persaman respon kecepatan turun untuk speed bump terhadap gaya tekan kendaraan diberikan oleh persamaan sebagai berikut :

$$
\dot{x}(t)=\frac{\dot{I} e^{-\zeta \omega_{n} t}}{m \omega_{d}}\left(-\zeta \omega_{n} \sin \omega_{d} t+\omega_{d} \cos \omega_{d} t\right)
$$

dimana : $I$ adalah impuls, $m$ adalah massa kendaraan dan pengendara, $\varpi_{n}$ merupakan frekuensi natural sistem, $\varpi_{d}$ adalah frekuensi redaman dan $\zeta$ adalah rasio redaman.

\subsection{Simulasi Model SBEH}

Analisis simulasi dilakukan untuk memecahkan solusi numerik dengan model interaksi SBEH dan kendaraan yang telah diperkenalkan dalam sub-bagian 2.1 dengan menggunakan perangkat lunak komersial, MATLAB-Simulink seperti pada gambar 2 dibawah. Parameter kendaraan yang diadopsi ke dalam model kendaraan adalah mobil Toyota Avanza 1.3E M/T Minor Change dengan berat kosong 1020. Parameter model SBEH adalah sesuai dengan prototipe yang telah dibuat dan tercantum dalam Tabel 1. 


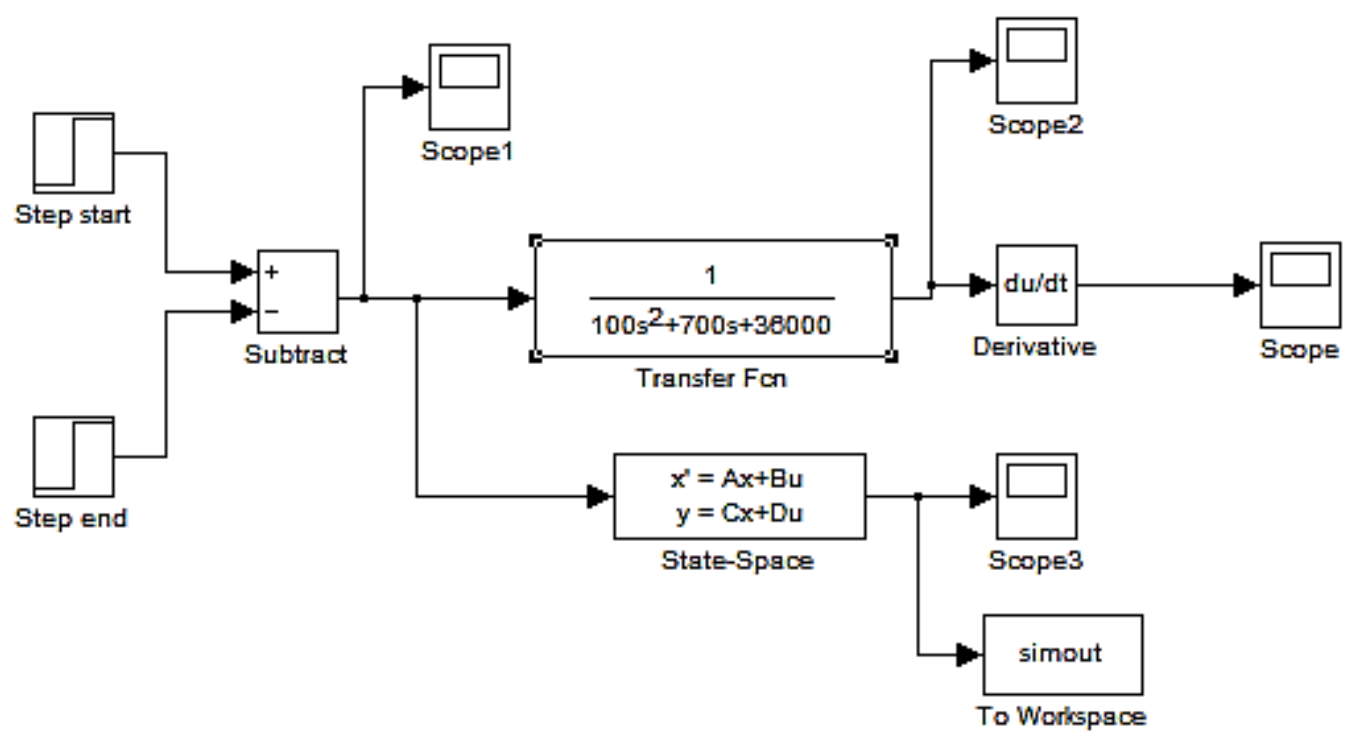

Gambar 2. Simulasi model SBEH dengan MATLAB-Simulink

Tabel 1. Nilai parameter model SBEH yang digunakan dalam simulasi MATLAB-simulink

\begin{tabular}{lcrl}
\hline Parameter & Notation & Parameter value \\
\hline Radius of Pinion Gear & $R$ & 0.0254 & $\mathrm{~m}$ \\
Sprung Mass & $M_{s}$ & 1527 & $\mathrm{~kg}$ \\
Un-Sprung Mass & $M_{u}$ & 200 & $\mathrm{~kg}$ \\
Speed Bump Mass & $M_{b}$ & 150 & $\mathrm{~kg}$ \\
Equivalent mass & $M_{e}$ & 620 & $\mathrm{~kg}$ \\
Total Mass (Speed bump and equivalent mass) & $M_{b}+M_{j}$ & 770 & $\mathrm{~kg}$ \\
Suspension Stiffness & $K_{s}$ & $60000 \mathrm{~N} / \mathrm{m}$ \\
Tire stiffness & $K_{s}$ & $440000 \mathrm{~N} / \mathrm{m}$ \\
Speed bump stiffness & $K_{b}$ & $130000 \mathrm{~N} / \mathrm{m}$ \\
Suspension damping coefficient & $C_{s}$ & $7000 \mathrm{~N}-\mathrm{s} / \mathrm{m}$ \\
SBEH electrical damping coefficient & $C_{e}$ & $400 \mathrm{~N}-\mathrm{s} / \mathrm{m}^{2}$ \\
Gravitational constant & $g$ & $9.8 \mathrm{~m} / \mathrm{s}$ \\
Gear Ratio & $n$ & 50 to 1
\end{tabular}

\section{Hasil dan Pembahasan}

Kinerja dinamis dari simulasi SBEH dan kendaraan yang melewati speed bump dilakukan dengan kondisi awal dengan kecepatan kendaraan $5 \mathrm{~km} / \mathrm{jam}, 10 \mathrm{~km} / \mathrm{jam}$ dan $15 \mathrm{~km} / \mathrm{jam}$.

Tabel 1. Pengaruh variasi kecepatan kendaraan terhadap respon kecepatan turun speed bump

\begin{tabular}{ccc}
\hline $\begin{array}{c}\text { Kec. Mobil } \\
(\mathbf{K m} / \mathbf{j a m})\end{array}$ & $\begin{array}{c}\text { Kec. Respon } \\
\text { SB-F(m/s) }\end{array}$ & $\begin{array}{c}\text { Kec. Respon } \\
\text { SB-R(m/s) }\end{array}$ \\
\hline 5 & 2,3 & 2,19 \\
10 & 1,99 & 1,87 \\
15 & 1,54 & 1,38 \\
\hline
\end{tabular}

Respon kecepatan turun speed bump terhadap variasi perubahan kecepatan kendaraan di berikan pada Tabel 2. Semakin besar cepat kendaraan yang melintasi 
speed bump dengan massa yang sama maka kecepatan turun sebagai respon yang dihasilkan oleh speed bump akan menjadi kecil. Atau dengan kata lain, semakin besar lambat kendaraan yang melintasi speed bump dengan massa yang sama maka kecepatan turun sebagai respon yang dihasilkan oleh speed bump akan menjadi besar.

\section{Kesimpulan}

Dari hasil penelitian desain dan simulasi speed bump model SBEH ini dihasilkan kecepatan turun maksimum yang dihasilkan kurang lebih 2,3 m/s ketika sebuah kendaraan melewati prototipe tersebut dengan kecepatan rata-rata $5 \mathrm{~km} / \mathrm{jam}$.

\section{Ucapan terima kasih}

Terima kasih kami ucapkan kepada DRPM UNPAD yang telah mendanai penelitian ini dengan skema HPKRD pada tahun anggaran 2016 dengan surat kontrak nomor : 1094/UN6.3.1/PL/2016.

\section{Daftar Pustaka}

1. E. Khorshid, F. Alkalby, and H. Kamal, (2007). Measurement of whole-body vibration exposure from speed control humps, J. Sound Vib., vol. 304, no. 3-5, 640-659.

2. H. Ansari Ardeh, M. Shariatpanahi, and M. N. Bahrami. (2008). Multiobjective shape optimization of speed humps, Struct. Multidiscip. Optim., vol. 37, no. 2, 203-214.

3. S. Arabia. (1982). Dynamic considerations of speed control humps (a) Hump profile, vol. I, no. 4, 291-302.

4. D. Garcia-Pozuelo, A. Gauchia, E. Olmeda, and V. Diaz. (2014). Bump Modeling and Vehicle Vertical Dynamics Prediction, Adv. Mech. Eng., vol. 2014,1-10.

5. P. Taylor, T. Abiola, O. Salau, A. O. Adeyefa, and S. A. Oke. (2014). Vehicle speed control using road bumps," Transport, Vol XIX, No 3, 130-136.

6. D. Chambers. (2014). Final project report assessment of piezoelectric materials for roadway energy Cost of Energy and Demonstration Roadmap.

7. S. Andriopoulou. (2012). A review on energy harvesting from roads, 1-39.

8. S. Priya, and D. Inman. (2009). Energy harvesting technologies, Vol. 21, Springer, New York, 